\title{
The Effect of Positive Thinking on Internal Corporate Communication in the Context of Positive Communication: A Review of the State Oil Company of Azerbaijan Republic (SOCAR)
}

\author{
Pozitif İletişim Bağlamında Olumlu Bakış Açısının Kurum İçi İletişime Etkisi:State Oil Company of \\ Azerbaijan Republic (SOCAR) Şirketi Üzerine Bir Inceleme
}

\author{
Nargiz MURADOVA \\ nargizmuradova@bk.ru \\ https://orcid.org/0000-0002-6888-2009
}

$\begin{array}{ll}\text { Received } & : 02.05 .2021 \\ \text { Revised } & : 14.12 .2021 \\ \text { Accepted } & : 15.12 .2021 \\ \text { Type of Article } & : \text { Research }\end{array}$

\begin{abstract}
Keywords:

Positive

Communication,

Positive Thinking,

Internal

Communication,

SOCAR

\section{Anahtar Kelimeler: \\ Pozitif İletişim \\ Pozitif Düşünme, \\ Kurum İçi İletişim,}

SOCAR

The purpose of this study is to examine and reveal the effect of positive thinking on internal communication in the context of positive communication. The research consists of three parts. In the first part, the concept of corporate communication, in the second part, the concept of positive communication and positive thinking, in the third part, the demographic characteristics of the participants, the results of the analysis made to determine the relationship between positive thinking and internal communication are mentioned. In this research, a survey was conducted on SOCAR employees. The analysis of the data was conducted with the SPSS 21.0 (Statistical Package for Social Sciences) program package. Means, standard deviations and percentages are given as descriptive statistics. An independent sample t-test was used for comparisons of parametric binary variables. One Way ANOVA was used for the comparisons of categorical variables with more than two categories, and the F test was used for the comparisons of non-parametric variables with more than two categories. The results obtained were evaluated at a 95\% $(p<0.05)$ significance level. As a result of the study, positive thinking skills were found to be influential on internal communication. In other words, improving employees' positive thinking skills also positively affects their internal communication.

ÖZET

Bu çalışmanın amacı, pozitif iletişim bağlamında olumlu düşüncenin kurum içi iletişsime olan etkisinin incelenmesi ve ortaya koyulmasıdır. Araştırma üç bölümden oluşmaktadır. Birinci bölümde kurumsal iletişim ve kurum içi kavramından, ikinci bölümde pozitif iletişim ve olumlu düşünce kavramından, üçüncü bölümde ise katılımclların demografik özellikleriyle ilgili dağılım ve olumlu düşüncenin kurum içi iletişsime olan etkisini belirlemek üzere yapılan analizlerden ve araştırmanın sonucundan bahsedilmiştir. Bu araştırmada SOCAR şirketi çalışanları üzerinde anket çalışması yapılmıştır. Verilerin analizi ise SPSS 21.0 (Statistical Package for Social Sciences) paket programı ile analiz edilmiştir. Tanımlayıcı istatistikler olarak ortalama, standart sapma ve yüzde dă̆ılımlar verildi. Parametrik olan ikili değişkenlere ilişkin karşılaştırmalarda bă̆ımsız örneklem $t$ testi kullanıldl. Parametrik olan ikiden fazla parametreye sahip değiş̧kenlere ilişkin karşılaştırmalarda One Way ANOVA, parametrik olmayan ikiden fazla parametreye sahip değişkenlere ilişskin karşılaştırmalarda $F$ testi uygulandi. Elde edilen sonuçlar \%95 $(p<0.05)$ anlamlılık düzeyinde değerlendirildi. Araştırma sonucunda olumlu düşünme becerileri kurum içi iletişim üzerinde etkilidir. Başka bir ifade ile çalışanların olumlu düşünme becerileri arttıkça kurum içi iletişim düzeyi becerileri de artmaktadır.
\end{abstract}




\section{INTRODUCTION}

Communication is related to all activities of human life. Communication is a social phenomenon and enables the sharing of meanings between individuals or groups. Its main goal is to allow people to be influential on people around them. Corporate communication is the communication that occurs in an organization for the accomplishment of the organizational goals. Corporate communication is not the communication established just within the institution, but the communication established inside or outside the company for the accomplishment of organizational goals. The investment made in corporate communication will make the communication of employees with each other healthier and more efficient. The role of internal communication in business life is indispensable. We spend a significant proportion of our lives with our colleagues at our workplaces. This shows that our work has an important part in our lives. Everyone wants to have a happy and peaceful work environment and mutual efforts are made to achieve this.

In the current study, the effect of positive thinking on internal communication in the context of positive communication was examined. In the study, it was also investigated whether the participants' positive thinking skills and perceptions of internal communication vary depending on demographic variables such as gender, age, marital status and education level. In the current study, an analysis was conducted on the "State Oil Company of Azerbaijan Republic" (SOCAR). This analysis was conducted on a total of 210 questionnaires. In the analysis of the collected data, SPSS 21.0 (Statistical Package for Social Sciences) program package was used and means, standard deviations and percentages were calculated as descriptive statistics. In the comparison made in relation to binary variables, independent samples t-test was used. In the comparisons made with parametric variables having more than two categories, One Way ANOVA was used while in the comparisons to non-parametric variables having more than two categories, Turkey test was used. The data obtained were evaluated at the significance level of 0.05 .

\section{INTERNAL COMMUNICATION, POSITIVE COMMUNICATION AND POSITIVE THINKING}

\subsection{Internal Communication}

As a result of the rapid development of technology, people have lost the concept of time and are trying to keep up with an accelerated world and to benefit from technology to the greatest extent. All these developments bring about many problems while people are trying to comprehend the new world and find a place in it. While people struggle to gain a place in life, to show themselves strong and to keep up with a fast life, they also encounter problems such as lack of communication, negligence, lack of satisfaction and stress. These kinds of negative situations brought about by the course of life have formed the basis of communication problems between managers and employees and between employees and employees in organizations. Seen from positive perspectives, various communication tools offered to us have given us the opportunity to choose the most suitable and efficient communication tools (Dolphin, 1999, p. 58).

In order to be able to talk about internal communication, we first need to understand what internal communication is: "Internal communication is a social process that enables a continuous exchange of information and ideas between the various departments and elements that make up the organization and between the organization and its environment, or the establishment of necessary relations between the departments in order to ensure the correct functioning of the organization and achieve its goals" (Eroğluer, 2011, p. 1410).

Based on the above definition, ensuring the functioning of the organization towards the determined goals and accomplishment of its goals can be possible through the establishment of positive internal communication. It is important to ensure harmony between employees working in an organization by placing emphasis on manageremployee communication, creating a collaborative work environment and motivating employees. It should not be overlooked that it is the employees of the organization that represent the organization and reflect the image, mission and vision of the organization to the external environment, customers, and thus they contribute to the accomplishment of organizational goals and its development.

Kohtes and Klewes suggest that organizations should ensure internal communication by informing, motivating and managing their employees. What is meant by informing the employees is informing them about the goals, strategies, daily work, products and services of the organization so that they can get to know their work areas and work more efficiently. At the same time, organizations should motivate their employees and get them to feel a 
sense of satisfaction by positively influencing their feelings and thoughts. Most importantly, organizations should manage their employees. It should enable the strengthening of internal communication by helping them to progress and find direction in the organization. All these processes should be strongly integrated with each other. Thus, we can state that the stages in internal communication should be outlined as follows:

- Accurate communication of the goals, vision and mission of the organization to its employees.

- In the organization, the manager should establish effective communication with his / her employees and thus determine the demands and satisfaction of the employees.

- Strong harmony and cooperation among the employees.

- Knowing the wishes and satisfaction of the employees, increasing their motivation and determination and making a strategic planning for their development.

When we look at it as a whole, as long as these main lines are preserved in internal communication, it becomes easier to fill other missing parts. Recruitment of employees in accordance with the mission and vision of the organization and the employees' understanding of the goals and objectives of the organization or the company contribute to their working more effectively and productively. Effective manager-employee communication will ensure the development of the employee by reinforcing the sense of commitment to the job. In terms of personal satisfaction, managers' encouragement of employees with awards will play an important role in increasing their motivation and developing the relationship of trust with the organization. These positive aspects, together with this trust relationship, loyalty to the organization, advanced communication between employees and the feeling of belongingness penetrate into the customer and bring the organization to a better position (Özel, 2012, p. 106).

When we look at the development of internal communication in corporate structures in general, we see a process that is directly proportional to the development of technology. First, while there were face-to-face communication and announcements made on billboards, then printed materials (news bulletins, annual reports, etc.) appeared. As technology developed, e-mail, social media, and the power of the digital world became a resource for internal communication. Ensuring effective internal communication is one of the important issues in order to use all these resources efficiently through developing internal communication.

\subsection{Positive Communication}

By saying that "You can say everything with the right key, but nothing with the wrong key; the main issue is the construction of the key", Bernard Shaw put forward the idea that forms the basis of "positive communication". Being a very important factor in human relations and communication, to act according to the situation, to apply communication tactics is an important principle of positive communication. With the communication established in this way, the quality of life and the status of human being increase. The important factors of positive communication can be listed as follows: Understanding each other by establishing mutual empathy, listening to the other person without interrupting his/her words, asking questions that do not have a negative purpose, sometimes expressing feelings to the other person with body language, being able to share thoughts freely and without hesitation, being able to act according to the situation when needed, and being able to look into the eye of the other person while communicating. In positive communication, individuals empathize with each other and at the same time foster positive emotions. Communication is based on mutual understanding and parties' respecting each other (Kaya, 2014, p. 15). It is necessary to make an effort to create positive communication. Of course, it is not possible to communicate positively with all people, but it is in the hands of people to understand the other person, to take an attitude according to the situation, to listen to the other person sincerely and to translate this into positive communication (Çakır \& Ünal, 2019, p. 936). Communication researcher Jack Gibb mentions the following attitudes that lead to positive communication (Çeşitcioğlu, 2007, p. 17):

\subsection{Positive Thinking}

Man is subject to a law of evolution, not a being created by chance. As with the visible world and material things, man is an absolute constant in the hidden realm of thought, with the absolute relationship of cause and effect. A noble and lofty character is not about being privileged or lucky, but a sum of striving for righteous thinking and lofty thoughts that are firmly abided by. Dishonourable and bad character, from the same point of view, is due to the constant harbouring of bad thoughts in the individual (Allen, 2019, p. 8).

Positive thinking is using the mind by controlling and directing it in a positive way. According to some academicians and researchers, the attitudes and judgments of the individual are directly related to the information. The available information includes feelings and thoughts on that subject. Any communication or event that has a positive effect on the mind of the individual will relieve him/her (Bilge, 2012, p. 12). As a being with power, 
MURADOVA, Nargiz - The Effect of Positive Thinking on Internal Corporate Communication in the Context of Positive Communication: A Review of the State Oil Company of Azerbaijan Republic (SOCAR)

intelligence and love and as the master of his own thoughts, man has the key to every situation. With his transformative and refreshing power, he can build himself however he wants (Allen, 2019, p. 9).

If we want to influence our behaviour or performance, we can only do so with our subconscious mind. For this, we have to choose new, positive thoughts, and they are constantly rooted in our subconscious mind. Repetitive negative thoughts create negative consequences: we need to turn this around. The quality of our thoughts determines the quality of our life (Peiffer, 2003, p. 17).

Positive thinking is the ability to see the bright side of things and makes people more creative and constructive. Positive thinking is also linked to positive emotions, optimism, hope, joy, and happiness (Karadağ, 2019, p. 132). Positive thinking is a choice. It is a decision about how you will look at things. It is finding the good in the bad. Positive thinking is finding one's own positive sides and striving for something bigger than himself/herself by combining these positive aspects (Kan, 2017, p. 29). Positive thinking skill is one of the skills that can provide many advantages to individuals in the course of life. Many studies have shown that positive thinking skill is an important factor related to coping with stress and anxiety, problem-solving, happiness, academic performance and even health (Naseem and Khalid, 2010:53).

\section{METHOD}

\subsection{Purpose and Significance of the Study}

The organization is an order established with the aim of doing together what people cannot do alone. The togetherness mentioned here is to achieve the goal in accordance with the purpose of the work by doing the work together and incoordination. In this sense, what brings people together is communication. The contribution of internal communication to the motivation and productivity of a person in business life is an undeniable fact. In this regard, the current study focused on the effect of positive thinking on the internal communication within the context of positive communication in SOCAR. To this end, the current situation is defined and analyzed and interpretations are made through a scientific method.

It is thought that positive thinking skills will positively affect internal communication and that individuals with these skills will have strong internal communication. The purpose of the current study is to reveal the effects of positive thinking skills on internal communication. When it comes to the significance of the study, business life and our colleagues have an important place in our lives. Organizations now value their employees and understand that success comes from positive energy. Employees can defend their thoughts freely and openly. Now, one of the most important principles of management is to invest in its employees, to accept that they are a part of companies and to support them by establishing positive communication.

\subsection{Population and Sample of the Study}

The population of the study is comprised of individuals working in SOCAR. A total of 210 employees selected from the population by using the convenience sampling method constitute the sample. The convenience sampling method allows the inclusion of the individuals meeting some pre-determined criteria in a non-random manner in the sample. Within the context of the study, an analysis was conducted on the "State Oil Company of Azerbaijan Republic" (SOCAR). In the study, the Corporate Communications departments in both Baku and Istanbul were contacted and information exchange was made. When we examine the company, we can see that Corporate Communication activities are actively managed. It has achieved many successes and has also received many awards. In the study conducted by the Great Place to Work (GPTW) institute, which attaches great importance to internal communication in many countries, in 2019, SOCAR was in the list of the companies classified as great places to work in Turkey. It was also on the lists of the great places to work in 2015 and 2018 (SOCAR Türkiye, 2019). In addition, it has also achieved many other successes such as the most reputable energy company of the year, the third-time winner of the Gold Award in the Energy Category at the Social Media, and one of the best employers of 2019.

\subsection{Data Collection Tools}

In the current study, the processes of the quantitative research method were followed in order to collect and analyze the data to test the hypotheses determined before. Accordingly, the questionnaire method was used to collect data. First, the criteria of the individuals to be included in the study were determined and the questionnaire items were entered into the online environment. The first question asked to the participants was arranged as a selective question, and their state of having made a job application to an institution / organization and having received a negative answer was determined. The questionnaire consists of three parts; 
1. Demographic features form

2. Positive Thinking Skills Scale

3. Internal Communication Scale

Cronbach's Alpha coefficients of the scales used in the current study are shown in Table 1.

Table 1. Reliabilities of the Scales Used in the Study

\begin{tabular}{|c|c|c|}
\hline Scales & Item Numbers & $\begin{array}{c}\text { Cronbach's } \\
\text { Alpha }\end{array}$ \\
\hline Positive Thinking Skills Scale & $1-8$ & .814 \\
\hline Internal Communication Scale & $1-17$ & .932 \\
\hline
\end{tabular}

\subsubsection{Demographic Information Form}

Questionnaires and scales whose validity and reliability have been tested with previous studies in the literature are used as data collection tools in the study. The questionnaire form used in the current study consists of three parts. In the first part, there is a personal information form developed to elicit information about sociodemographic features of the individuals working in SOCAR. In this personal information form, there are questions to elicit information about demographic features of the individuals working in SOCAR such as gender, marital status, age, length of service, education level and position in the organization. The form has five questions. In addition, there are two scales in the questionnaire; the Positive Thinking Skills Scale and the Internal Communication Scale.

\subsubsection{Positive Thinking Skills Scale}

This is a uni-dimensional scale consisted of 8 items. The scale is designed in the form of a 4-point Likert scale. The validity and reliability studies of the Turkish form of the scale were conducted by Akın, Uysal and Akın (2015). In their study, the Cronbach Alpha coefficient of the scale was calculated to be 0.814 .

\subsubsection{Internal Communication Scale}

In the current study, the Internal Communication Scale developed by Cengizalp (2003) was used to determine the participants' level of internal communication. The Internal Communication Scale is comprised of 17 items and 3 sub-dimensions called communication with colleagues, communication with managers and corporate communication policy. The scale is designed in the form of a 5-point Likert scale ranging from "Strongly Agree" to "Strongly Disagree". The validity and reliability studies of the scale were performed by Cengizalp (2003). The Cronbach Alpha internal consistency coefficient of the whole scale was calculated to be .86. The Cronbach alpha internal consistency coefficients calculated for the sub-dimensions are as follows; .87 for communication with colleagues, .83 for communication with managers, .89 for corporate communication policy.

\subsection{Statistical Analysis of the Research Data}

In the current study, demographic and professional information about the participants is presented in the form of percentages and frequencies. The Kurtosis and skewness values were taken into consideration in the examination of the normality of the distribution of the scores taken from the Positive Thinking Skills Scale and Internal Communication Scale. According to George and Mallery (2010), if the skewness and Kurtosis values are between +2.0 and -2.0 and according to Tabachnick and Fidell (2013), if these values are between +1.5 and -1.5 , the scale is considered to be normally distributed and parametric tests are accepted to yield more valid and reliable results. In this connection, as the skewness and Kurtosis values of the scales were found to be between +2.0 and -2.0 , some of the parametric tests, One-Way ANOVA, independent samples t-test, Pearson correlation analysis and regression analysis were used in the current study.

\subsection{Hypotheses}

In the current study, the effect of positive thinking on the internal communication within the context of positive communication was investigated. In this context, the hypotheses developed in the current study are given below: $\mathrm{H} 1=$ There is a positive and significant correlation between positive thinking skills and internal communication. 
MURADOVA, Nargiz - The Effect of Positive Thinking on Internal Corporate Communication in the Context of Positive Communication: A Review of the State Oil Company of Azerbaijan Republic (SOCAR)

$\mathrm{H} 2=$ The level of positive thinking varies significantly depending on gender.

$\mathrm{H} 3=$ The level of positive thinking varies significantly depending on marital status.

$\mathrm{H} 4=$ The level of positive thinking varies significantly depending on age.

$\mathrm{H} 5=$ The level of positive thinking varies significantly depending on education level.

H6 $=$ The level of positive thinking varies significantly depending on the length of service.

$\mathrm{H} 7=$ The level of positive thinking varies significantly depending on the position.

$\mathrm{H} 9=$ The perception of internal communication varies significantly depending on gender.

$\mathrm{H} 10=$ The perception of internal communication varies significantly depending on marital status.

$\mathrm{H} 11=$ The perception of internal communication varies significantly depending on age.

H12 $=$ The perception of internal communication varies significantly depending on education level.

$\mathrm{H} 13=$ The perception of internal communication varies significantly depending on the length of service.

$\mathrm{H} 14=$ The perception of internal communication varies significantly depending on the position.

\section{FINDINGS}

In this section of the study, findings related to the effect of positive thinking on internal communication and whether the participants' positive thinking skills and perception of internal communication vary significantly depending on the demographic variables of gender, age, marital status, education level, position and length of service are presented. In Table 2, findings related to the demographic features of the participants working in SOCAR are given.

Table 2. Participants' Socio-demographic Features

\begin{tabular}{|c|c|c|c|}
\hline & Features & $\mathbf{N}$ & $\%$ \\
\hline \multirow{2}{*}{ Gender } & Female & 106 & 50.5 \\
\hline & Male & 104 & 49.5 \\
\hline \multirow{2}{*}{ Age } & $20-25$ & 54 & 25.7 \\
\hline & $26-40$ & 156 & 74.3 \\
\hline \multirow{2}{*}{ Marital Status } & Married & 93 & 44.3 \\
\hline & Single & 117 & 55.7 \\
\hline \multirow{4}{*}{ Education Level } & High School & 22 & 10.5 \\
\hline & Undergraduate Degree & 89 & $\overline{42.4}$ \\
\hline & Master's Degree & 68 & 32.4 \\
\hline & Doctoral Degree & 31 & 14.8 \\
\hline \multirow[b]{2}{*}{ Position } & $\begin{array}{l}\text { I do not have an administrative duty } \\
\text { in the company }\end{array}$ & 150 & 71.4 \\
\hline & $\begin{array}{l}\text { I have an administrative duty in the } \\
\text { company }\end{array}$ & 60 & 28.6 \\
\hline \multirow{3}{*}{ Length of Service } & $0-6$ years & 112 & 53.3 \\
\hline & $7-12$ years & 69 & 32.9 \\
\hline & 13 years and longer & 29 & 13.8 \\
\hline
\end{tabular}

When the results presented in Table 2 are examined, it is seen that the majority of the participants are in the age group of 26-40 and do not have an administrative duty in the company. Moreover, nearly half of the participants are males, single, have been working for 0-6 years in the company and hold an undergraduate degree. The results of the analyses conducted to determine whether the mean scores taken by the participants from the Positive Thinking Skills Scale and the Internal Communication Scale vary significantly depending on the sociodemographic variables are presented below. 
Table 3. Results of the T-test Conducted to Determine whether the Participants' Mean Scores Taken from the Positive Thinking Skills Scale and the Internal Communication Scale Vary Significantly depending on Gender

\begin{tabular}{|c|c|c|c|c|c|c|}
\hline \multirow{2}{*}{ Scales } & Groups & $\mathbf{N}$ & $\overline{\mathbf{X}}$ & $\mathbf{S s}$ & $\mathbf{T}$ & P \\
\hline \multirow{2}{*}{ Positive Thinking Skills } & Female & 106 & 1.7911 & .43696 & \multirow{2}{*}{-.727} & .468 \\
\cline { 2 - 5 } & Male & 104 & 1.8393 & .52089 & & \multirow{2}{*}{ Internal Communication } \\
\cline { 2 - 6 } & Female & 106 & 3.8091 & .53605 & \multirow{2}{*}{-1.229} & .224 \\
\cline { 2 - 5 } & Male & 104 & 3.9095 & .65313 & & \\
\hline
\end{tabular}

In Table 3, the results of the t-test conducted to determine whether the participants' scores taken from the Positive Thinking Skills Scale and the Internal Communication Scale vary significantly depending on the gender are presented. When the results of the analysis are examined, it is seen that the mean scores taken from the Positive Thinking Skills Scale and the Internal Communication Scale do not vary significantly depending on gender $(\mathrm{p}>0.05)$. In other words, the mean positive thinking and internal communication scores of the male and female participants are similar. Thus, the hypotheses $\mathrm{H} 2$ and $\mathrm{H} 9$ are refuted.

Table 4. Results of the T-test Conducted to Determine whether the Participants' Mean Scores Taken from the Positive Thinking Skills Scale and the Internal Communication Scale Vary Significantly depending on Marital Status

\begin{tabular}{|c|c|c|c|c|c|c|}
\hline \multirow{2}{*}{ Scales } & Groups & $\mathbf{N}$ & $\overline{\mathbf{X}}$ & $\mathbf{S s}$ & $\mathbf{T}$ & $\mathbf{P}$ \\
\hline \multirow{2}{*}{ Positive Thinking Skills } & Married & 93 & 1.9094 & .50761 & \multirow{2}{*}{2.576} & \multirow{2}{*011}{} \\
\cline { 2 - 5 } & Single & 117 & 1.7399 & .44454 & & \multirow{2}{*}{2.211} \\
\hline \multirow{2}{*}{ Internal Communication } & Married & 93 & 3.9602 & .51238 & $\mathbf{. 0 2 8}$ \\
\cline { 2 - 5 } & Single & 117 & 3.7783 & .64841 & & \\
\hline
\end{tabular}

In Table 4, the results of the t-test conducted to determine whether the participants' scores taken from the Positive Thinking Skills Scale and the Internal Communication Scale vary significantly depending on the marital status are presented. When the results of the analysis are examined, it is seen that the mean scores taken from the Positive Thinking Skills Scale and the Internal Communication Scale vary significantly depending on marital status $(\mathrm{p}<0.05)$. In other words, the married participants' positive thinking skills and internal communication are significantly stronger than those of the single participants. Thus, the hypotheses H3 and H10 are supported.

Table 5. Results of the T-test Conducted to Determine whether the Participants' Mean Scores Taken from the Positive Thinking Skills Scale and the Internal Communication Scale Vary Significantly depending on Age

\begin{tabular}{|c|c|c|c|c|c|c|}
\hline Scales & Groups & $\mathbf{N}$ & $\overline{\mathbf{X}}$ & Ss & $\mathbf{T}$ & P \\
\hline \multirow{2}{*}{ Positive Thinking Skills } & $20-25$ & 54 & 1.6693 & .48212 & \multirow{2}{*}{-2.624} & \multirow{2}{*009}{} \\
\cline { 2 - 5 } & $26-40$ & 156 & 1.8654 & .47010 & & \\
\hline \multirow{2}{*}{ Internal Communication } & $20-25$ & 54 & 3.8410 & .57085 & \multirow{2}{*}{-.254} & .800 \\
\cline { 2 - 5 } & $26-40$ & 156 & 3.8650 & .60824 & & \\
\hline
\end{tabular}


In Table 5, the results of the t-test conducted to determine whether the participants' scores taken from the Positive Thinking Skills Scale and the Internal Communication Scale vary significantly depending on the age are presented. When the results of the analysis are examined, it is seen that the mean scores taken from the Positive Thinking Skills Scale vary significantly depending on age $(\mathrm{p}<0.05)$. In other words, the positive thinking skills of the participants aged 26-40 are significantly stronger than those of the participants aged 20-25. On the other hand, the participants' mean scores taken from the Internal Communication Scale were found to be not varying significantly depending on gender $(\mathrm{p}>0.05)$. That is, the internal communication levels of the participants from different age groups are similar. Thus, the hypothesis $\mathrm{H} 4$ is supported while the hypothesis $\mathrm{H} 11$ is refuted.

Table 6. Results of the ANOVA Conducted to Determine whether the Participants' Mean Scores Taken from the Positive Thinking Skills Scale and the Internal Communication Scale Vary Significantly depending on Length of Service

\begin{tabular}{|c|c|c|c|c|c|c|c|}
\hline Scales & Groups & $\mathbf{N}$ & $\overline{\mathbf{X}}$ & Ss & $\mathbf{F}$ & $\mathbf{P}$ & TUKEY \\
\hline \multirow{3}{*}{$\begin{array}{c}\text { Positive } \\
\text { Thinking Skills }\end{array}$} & $0-6$ years (a) & 112 & 1.7398 & .46150 & \multirow{3}{*}{13.264} & \multirow{3}{*}{.000} & \multirow{3}{*}{$a<b$} \\
\hline & $7-12$ years (b) & 69 & 1.7681 & .41077 & & & \\
\hline & $\begin{array}{l}13 \text { years and } \\
\text { longer }(\mathrm{c})\end{array}$ & 29 & 2.2167 & .51877 & & & \\
\hline \multirow{3}{*}{$\begin{array}{c}\text { Internal } \\
\text { Communication }\end{array}$} & $0-6$ years (a) & 112 & 3.7416 & .68205 & \multirow{3}{*}{9.651} & \multirow{3}{*}{.000} & \multirow{3}{*}{$\begin{array}{l}a<b \\
b<c\end{array}$} \\
\hline & $7-12$ years (b) & 69 & 3.8781 & .41500 & & & \\
\hline & $\begin{array}{c}13 \text { years and } \\
\text { longer (c) }\end{array}$ & 29 & 4.2657 & .41938 & & & \\
\hline
\end{tabular}

In Table 6, the results of the ANOVA conducted to determine whether the participants' scores taken from the Positive Thinking Skills Scale and the Internal Communication Scale vary significantly depending on the length of service are presented. When the results of the analysis are examined, it is seen that the mean scores taken from the Positive Thinking Skills Scale and the Internal Communication Scale vary significantly depending on the length of service $(p<0.05)$. In other words, the positive thinking skills and internal communication of the participants working for 13 years and longer are significantly stronger than those of the participants working for 0-6 years and 7-12 years. Thus, the hypotheses H6 and H13 are supported.

Table 7. Results of the ANOVA Conducted to Determine whether the Participants' Mean Scores Taken from the Positive Thinking Skills Scale and the Internal Communication Scale Vary Significantly depending on Education Level

\begin{tabular}{|c|c|c|c|c|c|c|c|}
\hline Scales & Groups & $\mathbf{N}$ & $\overline{\mathbf{X}}$ & Ss & $\mathbf{F}$ & $\mathbf{P}$ & TUKEY \\
\hline \multirow{4}{*}{$\begin{array}{l}\text { Positive } \\
\text { Thinking } \\
\text { Skills }\end{array}$} & High school (a) & 22 & 1.506 & .6040 & \multirow{4}{*}{15.468} & \multirow{4}{*}{.000} & \multirow{4}{*}{$\begin{array}{l}a<b \\
a<d\end{array}$} \\
\hline & Undergraduate (b) & 89 & 1.812 & .3594 & & & \\
\hline & Master's (c) & 68 & 1.716 & 4731 & & & \\
\hline & Doctoral (d) & 31 & 2.258 & 4180 & & & \\
\hline \multirow{4}{*}{$\begin{array}{c}\text { Internal } \\
\text { Communicati } \\
\text { on }\end{array}$} & High school (a) & 22 & 3.893 & .6825 & \multirow{4}{*}{5.692} & \multirow{4}{*}{.001} & \multirow{4}{*}{$\begin{array}{l}b<d \\
c<d\end{array}$} \\
\hline & Undergraduate (b) & 89 & 3.747 & .6385 & & & \\
\hline & Master’s (c) & 68 & 3.820 & .5071 & & & \\
\hline & Doctoral (d) & 31 & 4.239 & 4482 & & & \\
\hline
\end{tabular}

In Table 7, the results of the ANOVA conducted to determine whether the participants' scores taken from the Positive Thinking Skills Scale and the Internal Communication Scale vary significantly depending on the 
education level are presented. When the results of the analysis are examined, it is seen that the mean scores taken from the Positive Thinking Skills Scale and the Internal Communication Scale vary significantly depending on education level $(p<0.05)$. In other words, the positive thinking skills and internal communication of the participants holding a doctoral degree are significantly stronger than those of the participants with a lower level of education. Thus, the hypotheses H5 and H12 are supported.

Table 8. Results of the T-test Conducted to Determine whether the Participants' Mean Scores Taken from the Positive Thinking Skills Scale and the Internal Communication Scale Vary Significantly depending on Position

\begin{tabular}{|c|c|c|c|c|c|c|}
\hline Scales & Groups & $\mathbf{N}$ & $\overline{\mathbf{X}}$ & Ss & $\mathbf{T}$ & $\mathbf{P}$ \\
\hline \multirow{2}{*}{$\begin{array}{l}\text { Positive Thinking } \\
\text { Skills }\end{array}$} & $\begin{array}{l}\text { I do not have an administrative } \\
\text { duty in the company }\end{array}$ & 150 & 1.7333 & .42380 & \multirow{2}{*}{-4.039} & \multirow{2}{*}{.000} \\
\hline & $\begin{array}{c}\text { I have an administrative duty } \\
\text { in the company }\end{array}$ & 60 & 2.0190 & .55013 & & \\
\hline \multirow{2}{*}{$\begin{array}{c}\text { Internal } \\
\text { Communication }\end{array}$} & $\begin{array}{c}\text { I do not have an administrative } \\
\text { duty in the company }\end{array}$ & 150 & 3.7675 & .58377 & \multirow{2}{*}{-3.602} & \multirow{2}{*}{.000} \\
\hline & $\begin{array}{l}\text { I have an administrative duty } \\
\text { in the company }\end{array}$ & 60 & 4.0873 & .57457 & & \\
\hline
\end{tabular}

In Table 8, the results of the t-test conducted to determine whether the participants' scores taken from the Positive Thinking Skills Scale and the Internal Communication Scale vary significantly depending on the position are presented. When the results of the analysis are examined, it is seen that the mean scores taken from the Positive Thinking Skills Scale and the Internal Communication Scale vary significantly depending on the position $(\mathrm{p}<0.05)$. In other words, the positive thinking skills and internal communication of the participants having an administrative duty are significantly stronger than those of the participants not having an administrative duty. Thus, the hypotheses $\mathrm{H} 7$ and $\mathrm{H} 14$ are supported.

Table 9. Relationship between Positive Thinking Skills and Internal Communication

\begin{tabular}{|c|c|}
\hline & Internal Communication \\
\hline Positive Thinking Skills & $.371^{* *}$ \\
\hline
\end{tabular}

In Table 9, the results of the Pearson correlation conducted to determine the correlation between positive thinking skills and internal communication are presented. When the results of the analysis are examined, it is seen that there is a positive and significant correlation between positive thinking skills and internal communication $(\mathrm{r}=0.371 ; \mathrm{p}=0.00)$. In other words, with improving positive thinking skills, the level of internal communication also improves.

Table 10. The Effect of Positive Thinking Skills on Internal Communication

\begin{tabular}{|c|c|c|c|c|c|}
\hline \multirow{2}{*}{$\begin{array}{c}\text { Model } \\
\begin{array}{c}\text { Dependent Variable: } \\
\text { Internal Communication }\end{array}\end{array}$} & \multicolumn{2}{|c|}{$\begin{array}{c}\text { Non-standardized } \\
\text { Coefficients }\end{array}$} & $\begin{array}{c}\text { Standardized } \\
\text { Coefficients }\end{array}$ & & \multirow{2}{*}{ B } \\
\cline { 2 - 5 } & Std. Error & Beta & T & Sig. \\
\hline Positive Thinking Skills & 3.020 &, 151 & & 20,064 &, 000 \\
\hline (Constant) & .462 &, 080 &, 371 & 5,763 &, 000 \\
\hline Sig. & \multicolumn{7}{|c|}{0.000} \\
\hline
\end{tabular}




\begin{tabular}{|c|c|}
\hline $\mathrm{F}$ & 33.212 \\
\hline $\mathrm{R}^{2}$ & 0.134 \\
\hline
\end{tabular}

In Table 10, the effect of positive thinking skills on internal communication is revealed by means of regression analysis. As a result of the model developed, positive thinking skills were found to have positive effects on internal communication $(\mathrm{p}<0.05)$. In other words, with the participants' improving positive thinking skills, their level of internal communication also improves. Thus, the hypothesis H1 is supported. Positive thinking skills explain $13.4 \%$ of the variance in internal communication.

\section{RESULTS}

Today, the concept of positive thinking has an important place in human life. While in the past, positive thinking in society was considered to be related to communication, data from recent clinical studies showed that it has a positive correlation with internal communication. But in modern societies, personal health is more comprehensive, including being positive. Positivity, defined as having a positive disposition or positive thinking, corresponds to the hidden dimension underlying life satisfaction, self-esteem, and optimism, which is influenced by people's cognition, emotions and actions. Positivity means that individuals have a positive orientation towards or positive appraisal of themselves, the future, and past experiences.

The ability to respond positively to failures and negative obstacles is very important for communication. Positive subjective experiences and positive individual traits help improve the quality of life and communication and prevent pathologies that occur when life is vicious and meaningless. Today, positive psychology is associated with research that investigates other positive aspects such as positive emotions and creativity, optimism, communication, flexibility, empathy, compassion, humour and life satisfaction. In particular, the study of psychological well-being includes examining the factors of happiness, positive character traits, and the perception of life purpose and satisfaction. The purpose of positive psychology is to concentrate on the science of positive human qualities that enhance internal communication. In other words, the main goal of positive psychology is well-being. The emphasis is on enhancing human development. A "good life" means a well-lived and fulfilling life. It is necessary to be positive, attractive, meaningful, successful and to connect with others through positive relationships.

It has been argued that positive speaking can contribute to the creation of an environment to support employees' performance and communication. Seen from this perspective, as positive communication skills improve, there occurs an improvement in the communication between the employee and the manager and thus the motivation of employees increases. Research shows that positive thinking positively affects communication. In the current study, the effect of positive thinking on the internal communication within the context of positive communication was examined. Moreover, it was investigated whether the participants' positive thinking skills and perceptions of internal communication vary depending on demographic variables such as gender, age, marital status and education level. In this regard, the participants' positive thinking skills and internal communication were found to be varying significantly depending on the position. In other words, the positive thinking skills and internal communication of the participants having an administrative duty were found to be significantly stronger than those of the participants not having an administrative duty. Similarly, Salik (2017) also found that the positive thinking skills of administrators are stronger but the difference is not statistically significant.

As a result of the current study, it was concluded that the internal communication of the male participants is better than that of the female participants but the difference is not statistically significant. In the study conducted by Tekin (2015), it was also found that internal communication did not vary significantly by gender. Another finding obtained in the current study is that the participants' positive thinking skills and internal communication were found to be varying significantly depending on education level. In other words, the positive thinking skills and internal communication of the participants holding a doctoral degree are significantly stronger than those of the participants with a lower level of education. On the contrary, Salık (2017) found that with increasing level of education, the level of positive thinking skills decreased but the difference between the groups was not statistically significant.

Moreover, the positive thinking skills and internal communication of the married participants were found to be significantly stronger than those of the single participants. Married couples support each other. They share happiness and sadness. This makes them think more positively compared to single individuals. Similarly, Sal1k 
(2017) also found that the positive thinking skills of married individuals are significantly better than those of single individuals. In the current study, it was also found that the positive thinking skills of the participants vary significantly depending on age. In other words, the positive thinking skills of the participants aged 26-40 are significantly better than those of the participants aged 20-25. On the other hand, the participants' internal communication was found to be not varying significantly depending on age. In addition, the positive thinking skills and internal communication of the participants having been working for 13 years or longer were found to be significantly stronger than those of the participants having been working for 0-6 years and 7-12 years. The longer you work, the more experience you have; therefore, the people working for longer periods may have more positive perceptions of events in the workplace.

As a conclusion, positive thinking skills are effective in internal communication. In other words, as the positive thinking skills of the employees improve, their internal communication improves as well. In light of the findings of the current study, it can be suggested that positive thinking skills of the employees should be developed to improve their internal communication. In further studies, a comparison can be made with the results of the current study by conducting research in different sectors and on different samples.

\section{REFERENCES}

ALLEN, J. (2019), “Düşüncenin Gücü”, İzmir: İkilem Yayınevi.

BILGE, A. (2012), "Yaşama Dair Olumlu Düşünce", Ege Üniversitesi Hemşirelik Fakültesi, 130-135.

ÇAKIR, H., \& ÜNAL, U. (2019), “İletişim Becerilerini İnşa Eden Faktörlerle İlgili İletişsim Fakültesi Öğrencileri Üzerine Karşılaştırmalı Bir Analiz", Erciyes İletişim Dergisi, 929-954.

ÇEŞITCIOĞLU, M. (2007), "Pozitif İletişim”, İstanbul: Kaizen Yayıncılık.

DOLPHIN, R. (1999), "The Fundamentals of Corporate Communication”, Oxford: Butterworth-Heinemann.

EROĞLUER, K. (2011), “Örgütsel İletişim ile İş Tatmini Unsurları Arasındaki İlişkiler: Kuramsal Bir İnceleme”, Ege Akademik Bakış, 1409-1424.

GEORGE, D., and MALLERY, M. (2010), "SPSS for Windows Step by Step: A Simple Guide and Reference", Boston.

KAN, M. (2017), “Olumlu Düşüncenin Gücü”, İstanbul: Maviçatı Yayınları.

KARADAĞ, Ș. (2019), "Üniversite Öğrencilerinde Olumlu Düşünme Becerisinin Kişilerarası İletişim Becerisi ile İlişkisi”, Anemon Muş Alparslan Üniversitesi Sosyal Bilimler , 131-136.

KAYA, A. (2014), Kişilerarası İlişkiler ve Etkili İletişim. Ankara: Pegem Akadami.

NASEEM, Z., \& KHALID, R. (2010), "Positive Thinking in Coping with Stress and Health Outcomes: Literature Review" Journal of Research and Reflections in Education, 42-61.

ÖZEL, E. K. (2012), "Kurum İçi İletişimin Kaliteye Olan Etkisi: Yeni İletişim Teknolojilerinin Kurum İçi İletişim Kalitesine Olan Etkisini Incelemeye Yönelik Bir Araştırma”, Sosyal Bilimler Araştırmaları, 110-111.

PEIFFER, V. (2003), “Çekim Yasasının Temeli”, (H. Yavuzer, Çev.) İstanbul: Alfa Yayıncılık.

SOCAR Türkiye. (2019), SOCAR Türkiye: http://www.socar.com.tr adresinden alınmıştır.

TABACHNICK, B.G., FIDELL, L.S. (2013), “Using Multivariate Statistics”, Boston: Pearson 